\title{
Computational virtual screening and structure-based design of some epidermal growth factor receptor inhibitors
}

\author{
Muhammad Tukur Ibrahim*, Adamu Uzairu, Sani Uba and Gideon Adamu Shallangwa
}

\begin{abstract}
Background: The foremost cause of cancer mortality worldwide was lung cancer. Lung cancer is divided into small cell lung cancer and non-small cell lung cancer (NSCLC). The latter is the main type of lung cancer that account for about 90\% of the cancer issues and estimate about $25 \%$ of the cancer mortality each year in the world. Among the types of lung cancer with about 1.5 million patients and less than 20\% survival rate is NSCLC. Overexpression of EGFR tyrosine kinase was recognized to be the cause of NSCLC. Therefore, there is a need to develop more EGFR inhibitors due to drug-resistance development by the mutation.

Result: Computational virtual screening on some epidermal growth factor receptor inhibitors (EGFR ${ }^{\text {8858R/T790M }}$ inhibitors or NSCLC therapeutic agents) against their target protein (EGFR tyrosine kinase receptor pdb entry 3IKA) was performed via molecular docking simulation and pharmacokinetics to identify hit compounds with a promising affinity toward their target. The hit compounds discovered were compound 22 with $-9.8 \mathrm{kcal} / \mathrm{mol}, 24$ with $-9.7 \mathrm{kcal} / \mathrm{mol}$, 17 with $-9.7 \mathrm{kcal} / \mathrm{mol}$, and 19 with $-9.5 \mathrm{kcal} / \mathrm{mol}$ respectively. These lead compounds were further subjected to drug-likeness and ADME prediction and found to be orally bioavailable. Six (6) new EGFR ${ }^{L 858 R T 790 M}$ inhibitors using compound 22 with the highest binding affinity as a template were designed.

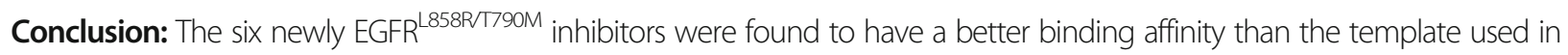
the designing process and AZD9291 (the positive control). None of the designed compounds was found to violate more than the permissible limit set by $\mathrm{RO} 5$ thereby predicting their easy transportation, absorption, and diffusion. More so, the designed compounds were found to have good synthetic accessibility which indicates that these designed compounds can be easily synthesized in the laboratory.
\end{abstract}

Keywords: Computational, Docking, EGFR ${ }^{L 58 R}$ T790M , Inhibitors, ADME, Drug-likeness

\section{Background}

Lung cancer is one of the leading cancer problems in the globe. It was reported to cause a lot of death every year (estimated to take about one-third of the entire cancer deaths). Non-small cell lung cancer (NSCLC) is the main subset of lung cancers that accounts for about $85 \%$ of the cancer problems [1]. Overexpression of epidermal growth factor receptor kinase was identified to be the common cause of NSCLCs.

\footnotetext{
* Correspondence: muhdtk1988@gmail.com

Department of Chemistry, Faculty of Physical Science, Ahmadu Bello University, P.M.B 1045, Zaria, Kaduna State, Nigeria
}

Report on NSCLCs on the population of patients in the Caucasia rise to about $10-15 \%$ and $30-40 \%$ in Asia [1].

The discovery of NSCLC therapeutic agents for the treatment of EGFR tyrosine kinase is one of the major challenges encountered by the medicinal chemist [2]. The treatment of EGFR tyrosine kinase to managed NSCLCs became a very urgent therapeutic necessity [3].

NSCLC therapeutic agents show a very high response rate in patients with arousing modifications of EGFR. NSCLC therapeutic agents or EGFR inhibitors are classified into reversible EGFR inhibitors (first-generation EGFR inhibitors); gefitinib and erlotinib are the example of this class of EGFR

\section{Springer Open}

(ㅇ The Author(s). 2020 Open Access This article is licensed under a Creative Commons Attribution 4.0 International License, which permits use, sharing, adaptation, distribution and reproduction in any medium or format, as long as you give appropriate credit to the original author(s) and the source, provide a link to the Creative Commons licence, and indicate if changes were made. The images or other third party material in this article are included in the article's Creative Commons licence, unless indicated otherwise in a credit line to the material. If material is not included in the article's Creative Commons licence and your intended use is not permitted by statutory regulation or exceeds the permitted use, you will need to obtain permission directly from the copyright holder. To view a copy of this licence, visit http://creativecommons.org/licenses/by/4.0/. 
Table 1 The Structures of the data set

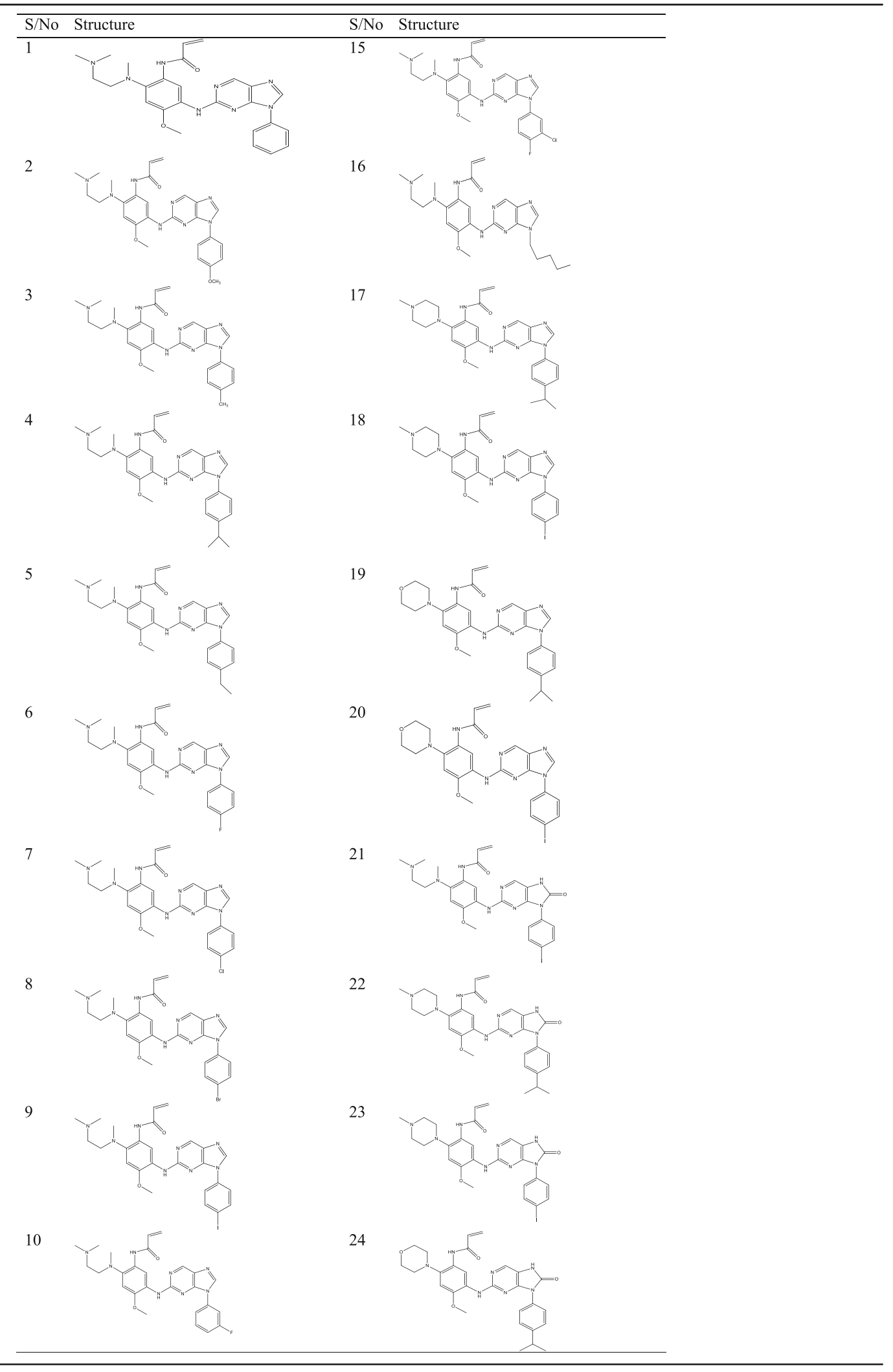




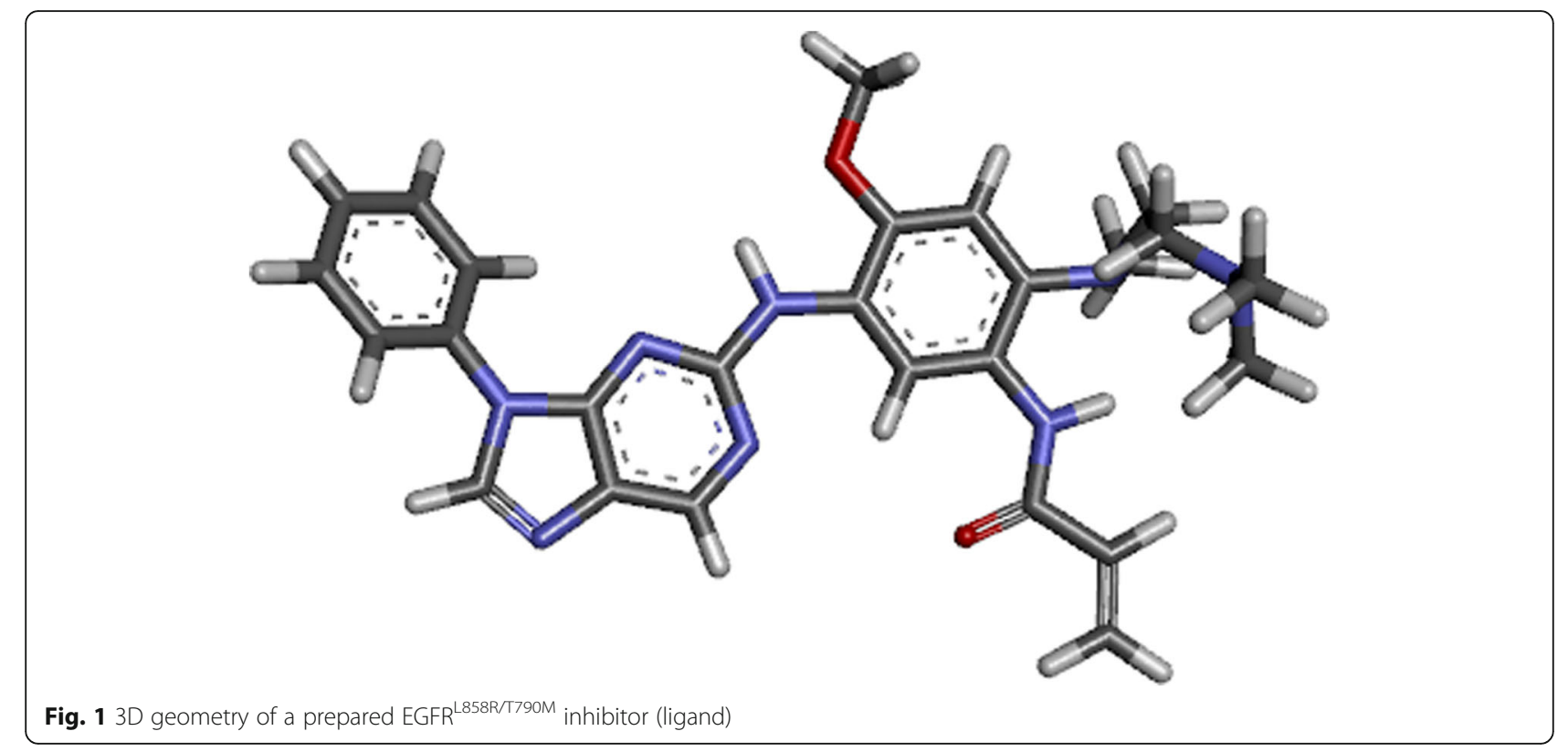

inhibitors include. Unluckily, the span of the potency of these first-generation EGFR inhibitors is narrowed due to the development of drug resistance by the secondary mutation T790M [4]. And the irreversible EGFR inhibitors (secondand third-generation EGFR inhibitors), afatinib and osimertinib, are the examples of these EGFR inhibitors. Inline to defeat the resistance to the first-generation of EGFR inhibitors, the second-generation irreversible EGFR inhibitors, such as afatinib and canertinib, were afterward devised to treat NSCLC EGFR T790M mutation [5]. Yet, due to severe side effects, such as skin rash and diarrhea, these secondgeneration inhibitors cannot attain satisfaction over the firstgeneration reversible inhibitors. It is believed that the activities upon wild-type EGFR will narrow the possible activities on the patients with the T790M mutation [2, 6-8].

To approach the unmet clinical demands, many thirdgeneration irreversible EGFR inhibitors, such as WZ-4002, rociletinib, olmutinib, and osimertinib were designed to inhibit the T790M resistance mutation while being more selective for wild type EGFR [2, 9-12].

Molecular docking is a molecular modeling technique used in structure-based design to screen a library of compounds to identify compounds with a higher affinity toward their target protein by elucidating their mode of interaction with their target utilizing their 3D structures [13]. Pharmacokinetics and drug-likeness properties prediction of hit compounds play a vital role in structure-based design in the determination of the pharmacokinetic profile of the hit compounds under investigation in the early stage of the drug pipeline [14].

This work is aimed at carrying out computational virtual screening on some EGFR ${ }^{\mathrm{L} 858 \mathrm{R} / \mathrm{T} 790 \mathrm{M}}$ inhibitors using molecular docking to identify hit compounds with a promising affinity against their target receptor (EGFR tyrosine kinase receptor), confirm their bioavailability via their pharmacokinetics and drug-likeness properties, and design new potent $\mathrm{EGFR}^{\mathrm{L} 858 \mathrm{R} / \mathrm{T} 790 \mathrm{M}}$ inhibitors that have better binding affinity than the template.

\section{Method}

This computational work was done on a Dell personal computer laptop, with these specifications: Intel ${ }^{\circ} \mathrm{Core}^{\mathrm{Tw}}$ i7 Dual CPU, M330@2.75 GHz $2.75 \mathrm{GHz}$, and $8 \mathrm{~GB}$ of RAM. The following software was utilized to achieve the success of this research: Pyrex virtual screening software,

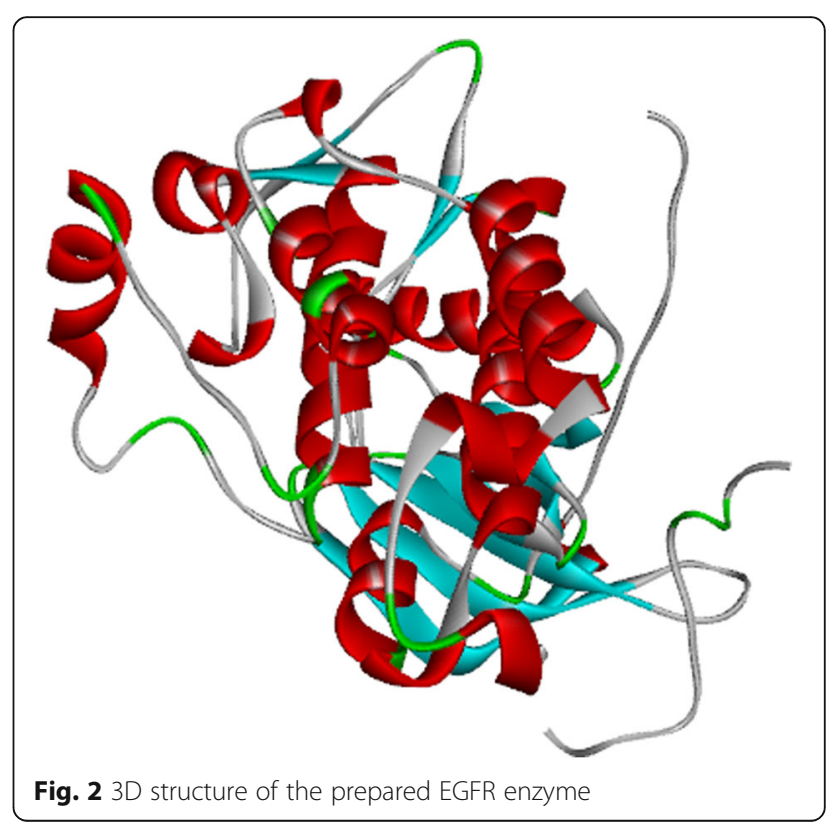


Table 2 The interactions of the molecules under investigation in the active site of EGFR receptor

\begin{tabular}{|c|c|c|c|c|}
\hline Complex & $\begin{array}{l}\text { Binding affinity } \\
\text { (Kcal/mol) }\end{array}$ & H Bond & $\begin{array}{l}\text { Bond } \\
\text { distance }(\AA)\end{array}$ & $\begin{array}{l}\text { Hydrophobic, electrostatic and Other } \\
\text { Interactions }\end{array}$ \\
\hline $\begin{array}{l}\text { Complex } \\
1\end{array}$ & -8.2 & $\begin{array}{l}\text { LYS745 } \\
\text { LYS875 } \\
\text { GLY857 } \\
\text { PHE723 }\end{array}$ & $\begin{array}{l}2.4833 \\
3.59309 \\
3.72533 \\
2.6702\end{array}$ & ASP855, LEU718, PHE723 and LEU844 \\
\hline $\begin{array}{l}\text { Complex } \\
2\end{array}$ & -8.0 & $\begin{array}{l}\text { ASP855 } \\
\text { MET790 } \\
\text { LYS745ASP855MET793GLY857PHE723 }\end{array}$ & $\begin{array}{l}2.98309 \\
2.54859 \\
2.53945 \\
3.28835 \\
3.63827 \\
3.69781 \\
2.74564\end{array}$ & ASP855, LEU718, PHE723 and LEU844 \\
\hline $\begin{array}{l}\text { Complex } \\
3\end{array}$ & -8.3 & $\begin{array}{l}\text { LYS745ASN842ASP855ASP837GLY857 } \\
\text { PHE723 }\end{array}$ & $\begin{array}{l}2.55654 \\
3.69674 \\
3.46169 \\
3.79142 \\
3.5789 \\
2.70142\end{array}$ & ASP855, LEU718, PHE723, LEU718 and LEU844 \\
\hline $\begin{array}{l}\text { Complex } \\
4\end{array}$ & -8.6 & LYS745ASN842GLY857PHE723 & $\begin{array}{l}2.57931 \\
3.47241 \\
3.71569 \\
2.53735\end{array}$ & $\begin{array}{l}\text { ASP855, MET790, PHE723, LEU718(3), VAL726, } \\
\text { ALA743 and LEU844 (2) }\end{array}$ \\
\hline $\begin{array}{l}\text { Complex } \\
5\end{array}$ & -8.4 & MET790LYS745ASN842ASP855LYS875GLY857PHE723 & $\begin{array}{l}2.63263 \\
2.57166 \\
3.5002 \\
3.48749 \\
3.7168 \\
3.61079 \\
2.69448\end{array}$ & $\begin{array}{l}\text { ASP855, LEU718 (2), PHE723, LEU792 and } \\
\text { LEU844 }\end{array}$ \\
\hline $\begin{array}{l}\text { Complex } \\
6\end{array}$ & -8.1 & $\begin{array}{l}\text { MET790ASP855LYS745LYS745 } \\
\text { ASP855 } \\
\text { GLY857 }\end{array}$ & $\begin{array}{l}2.63344 \\
2.45808 \\
2.51691 \\
2.75431 \\
3.42724 \\
3.68209\end{array}$ & ASP855, LEU718, PHE723 and LEU844 \\
\hline $\begin{array}{l}\text { Complex } \\
7\end{array}$ & -8.2 & MET790LYS745ASN842GLY857PHE723 & $\begin{array}{l}2.66828 \\
2.50517 \\
3.64733 \\
3.71982 \\
2.63929\end{array}$ & ASP855, LEU718 (2), PHE723 and LEU844 \\
\hline $\begin{array}{l}\text { Complex } \\
8\end{array}$ & -8.2 & MET790LYS745ASP855LYS875GLY857PHE723 & $\begin{array}{l}2.69124 \\
2.49593 \\
3.31777 \\
3.56354 \\
3.70766 \\
2.66609\end{array}$ & $\begin{array}{l}\text { ASP855, PHE723, LEU718 (2) } \\
\text { and LEU844 }\end{array}$ \\
\hline $\begin{array}{l}\text { Complex } \\
9\end{array}$ & -8.1 & $\begin{array}{l}\text { LYS745LYS745LYS87 } \\
\text { GLY857 } \\
\text { PHE723 }\end{array}$ & $\begin{array}{l}2.47818 \\
2.56406 \\
3.79409 \\
3.76916 \\
2.6504\end{array}$ & $\begin{array}{l}\text { PHE723, LEU718 (2) } \\
\text { and LEU844 }\end{array}$ \\
\hline $\begin{array}{l}\text { Complex } \\
10\end{array}$ & -8.2 & LYS745LYS745ASP855LYS875GLY857 & $\begin{array}{l}2.499 \\
2.82934 \\
3.37238 \\
3.46133 \\
3.67217\end{array}$ & ASP855, LEU844, PHE723, and ALA743 \\
\hline $\begin{array}{l}\text { Complex } \\
11\end{array}$ & -8.2 & LYS745LYS745ASN842LYS875:GLY857 & $\begin{array}{l}2.49654 \\
2.73608 \\
3.6529 \\
3.53467 \\
3.69398\end{array}$ & $\begin{array}{l}\text { ASP855, LEU844, PHE723 } \\
\text { ALA743, MET790, LEU844, LEU718, and ALA743 }\end{array}$ \\
\hline Complex & -8.3 & LYS745ASP855LYS875GLY857PHE723 & 2.57602 & ASP855, PHE723, LEU718 (2), and LEU844 \\
\hline
\end{tabular}


Table 2 The interactions of the molecules under investigation in the active site of EGFR receptor (Continued)

\begin{tabular}{|c|c|c|c|c|}
\hline Complex & $\begin{array}{l}\text { Binding affinity } \\
\text { (Kcal/mol) }\end{array}$ & $\mathrm{H}$ Bond & $\begin{array}{l}\text { Bond } \\
\text { distance }(\AA)\end{array}$ & $\begin{array}{l}\text { Hydrophobic, electrostatic and Other } \\
\text { Interactions }\end{array}$ \\
\hline 12 & & & $\begin{array}{l}3.16711 \\
3.67089 \\
3.72071 \\
2.58988\end{array}$ & \\
\hline $\begin{array}{l}\text { Complex } \\
13\end{array}$ & -8.3 & LYS745LYS745ASP855GLY857 & $\begin{array}{l}2.55105 \\
2.7272 \\
3.26506 \\
3.67378\end{array}$ & $\begin{array}{l}\text { ASP855, LEU718, PHE723, LEU718, LEU792, } \\
\text { MET793, LEU844, LEU844 }\end{array}$ \\
\hline $\begin{array}{l}\text { Complex } \\
14\end{array}$ & -8.3 & LYS745GLY796GLY857PHE723 & $\begin{array}{l}2.5629 \\
3.44018 \\
3.67278 \\
2.64954\end{array}$ & ASP855, LEU718 (2), PHE723 and LEU844 \\
\hline $\begin{array}{l}\text { Complex } \\
15\end{array}$ & -8.4 & $\begin{array}{l}\text { LYS745ASP855LYS875GLY79 } \\
\text { GLY857 } \\
\text { PHE723 }\end{array}$ & $\begin{array}{l}2.61401 \\
3.24347 \\
3.63358 \\
3.41857 \\
3.69224 \\
2.56581\end{array}$ & ASP855, PHE723, LEU718 (2), and LEU844 \\
\hline $\begin{array}{l}\text { Complex } \\
16\end{array}$ & -7.0 & ASP855LYS745GLY857 & $\begin{array}{l}2.56743 \\
2.30238 \\
3.46178\end{array}$ & ASP855, PHE723, LEU718, and VAL726 \\
\hline $\begin{array}{l}\text { Complex } \\
17\end{array}$ & -9.7 & MET790LYS745ASN842ASP855GLY857PHE723 & $\begin{array}{l}2.57246 \\
2.57583 \\
3.57065 \\
3.30557 \\
3.70673 \\
2.6945\end{array}$ & $\begin{array}{l}\text { ASP855, PHE723, LEU718 (3), LEU792, and } \\
\text { LEU844 }\end{array}$ \\
\hline $\begin{array}{l}\text { Complex } \\
18\end{array}$ & -9.0 & MET790ASP855LYS745LYS745ASP855LYS875GLY857 & $\begin{array}{l}2.78194 \\
2.60096 \\
2.56118 \\
2.63813 \\
3.35712 \\
3.54465 \\
3.735\end{array}$ & ASP855, PHE723, LEU718, and LEU844 \\
\hline $\begin{array}{l}\text { Complex } \\
19\end{array}$ & -9.5 & MET790LYS745ASP837ASP855GLY857PHE723 & $\begin{array}{l}2.59334 \\
2.64227 \\
3.57828 \\
3.31602 \\
3.68944 \\
2.673\end{array}$ & $\begin{array}{l}\text { ASP855, A:LEU718 (3), PHE723, LEU792, and } \\
\text { LEU844 }\end{array}$ \\
\hline $\begin{array}{l}\text { Complex } \\
20\end{array}$ & -9.0 & LYS745LYS745ASP837GLY857 & $\begin{array}{l}2.48189 \\
2.7112 \\
3.54803 \\
3.65017\end{array}$ & ASP855, PHE723, LEU718 (2), and LEU844 \\
\hline $\begin{array}{l}\text { Complex } \\
21\end{array}$ & -8.4 & ASP855LYS745LYS745ASP855 LYS875GLY857 & $\begin{array}{l}2.90321 \\
2.46076 \\
2.66728 \\
3.2402 \\
3.48286 \\
3.7513\end{array}$ & $\begin{array}{l}\text { ASP855, MET790, PHE723, LEU718 (2), } \\
\text { ALA743, and LEU844 (2) }\end{array}$ \\
\hline $\begin{array}{l}\text { Complex } \\
22\end{array}$ & -9.8 & MET790LYS745ASP855GLY857PHE723 & $\begin{array}{l}2.64611 \\
2.67379 \\
3.20518 \\
3.69658 \\
2.62473\end{array}$ & $\begin{array}{l}\text { ASP855,LEU844, MET790, PHE723, LEU718 (3), } \\
\text { ALA743, and LEU844 }\end{array}$ \\
\hline $\begin{array}{l}\text { Complex } \\
23\end{array}$ & -8.8 & LYS745GLY796ASP800 & $\begin{array}{l}2.48434 \\
2.7674 \\
3.71611\end{array}$ & $\begin{array}{l}\text { LYS745, ASP855, MET790, VAL726, LEU844, LEU718, } \\
\text { CYS797, and PHE723 }\end{array}$ \\
\hline $\begin{array}{l}\text { Complex } \\
24\end{array}$ & -9.7 & LYS745ASN842GLY857PHE723 & $\begin{array}{l}2.57931 \\
3.47241 \\
3.71569\end{array}$ & $\begin{array}{l}\text { ASP855, LEU844 (2), MET790, PHE723, LEU718 } \\
\text { (3),VAL726, and ALA743 }\end{array}$ \\
\hline
\end{tabular}


Table 2 The interactions of the molecules under investigation in the active site of EGFR receptor (Continued)

\begin{tabular}{lllll}
\hline Complex & $\begin{array}{l}\text { Binding affinity } \\
(\text { Kcal/mol) }\end{array}$ & H Bond & $\begin{array}{l}\text { Bond } \\
\text { distance }(\AA)\end{array}$ & $\begin{array}{l}\text { Hydrophobic, electrostatic and Other } \\
\text { Interactions }\end{array}$ \\
\hline & & & 2.53735 & \\
Complex & -9.3 & LYS745ASP837GLY857PHE723 & 2.47544 & ASP855, LEU718(2), LEU844 (2), MET790, PHE723, \\
25 & & 3.56847 & VAL726, ALA743 \\
& & 3.68984 & \\
Complex & -7.9 & 2.69826 & \\
26 & LYS745ARG841ASP837GLY857 & 2.72291 & ASP855, LEU718, VAL726, ALA743, and LEU844 \\
& & 2.36452 & \\
Complex & -7.6 & 3.7322 & \\
27 & & 3.53516 & \\
Complex & -8.1 & ASP855MET793 & 2.60582 & PHE723 and LEU858 \\
28 & & 3.54353 & \\
\hline
\end{tabular}
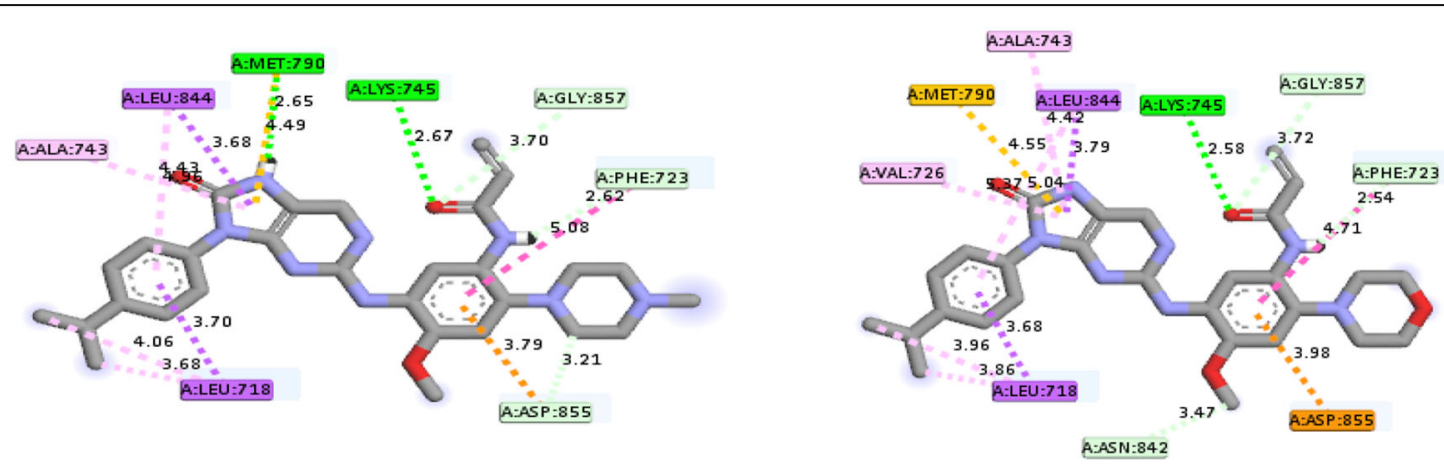

Interactions

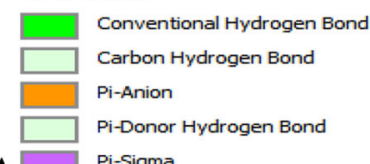

A Pi-Sigma

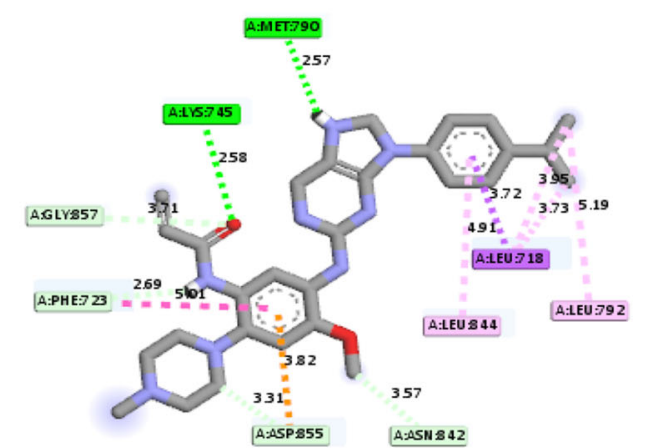

Interactions

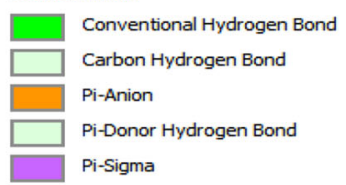

B

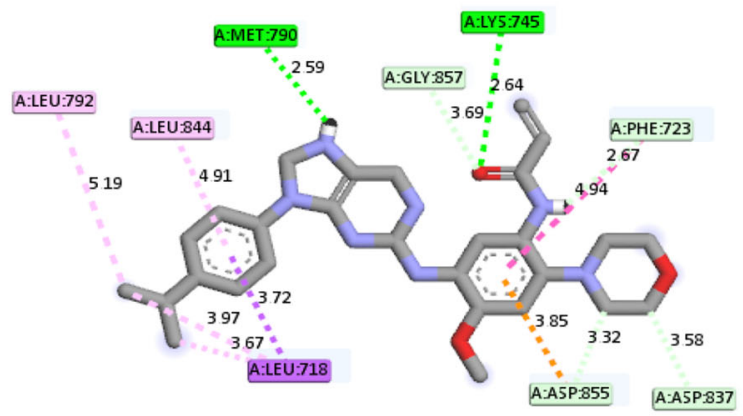

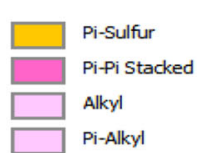

Pi-Alkyl

\section{Interactions}

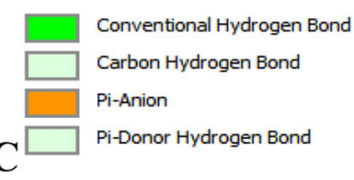

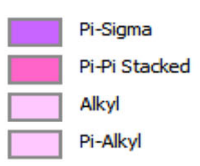

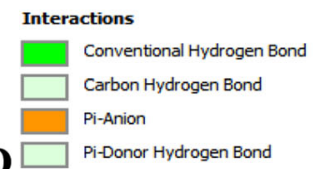

$\mathbf{D} \square$ Pi-Donor Hydrogen Bond

Fig. 3 2D and 3D structures of (a) Complex 22, (b) Complex 24, (c) Complex 17, and (d) Complex 19 using Discovery studio visualizer 
UCSF Chimera, PyMOL, Discovery studio, and SWISSA DME, an online web tool.

\section{Source and sketching of dataset under investigation} Twenty-eight (28) sets of EGFR ${ }^{\mathrm{L} 858 \mathrm{R} / \mathrm{T} 790 \mathrm{M}}$ inhibitors were gotten from the work of $\mathrm{Hu}$ et al. [15] and used in this research. Immediately after the retrieval of the data, the next thing is drawing of all the molecules under investigation in 2D format. Chemdraw software was then used to draw the 2D structures of all the molecules under investigation [16]. Table 1 presents the structures of all the data set under investigation.

\section{Determination of the optimum structures under investigation}

Determination of the most stable/optimum geometry of all the molecules on potential energy surface (PES) was achieved by the use of Spartan 14 wave software in this research. B3LYP/6-311G* level of theory with density functional theory (DFT) was used to achieve the searching for the optimum structures under investigation [17].

\section{Ligands, EGFR enzyme preparation and execution of the molecular docking simulation}

Ligands preparation is very vital in any molecular docking studies. As such, the preparation of the ligands in this work was done using the optimum geometry of each of the ligands obtained in 2.1 above before the elucidation of their binding interactions and the binding pose of the EGFR enzyme [18]. Figure 1 shows the 3D geometry of a prepared EGFR ${ }^{\mathrm{L} 858 \mathrm{R} / \mathrm{T} 790 \mathrm{M}}$ inhibitor (ligand) under investigation.

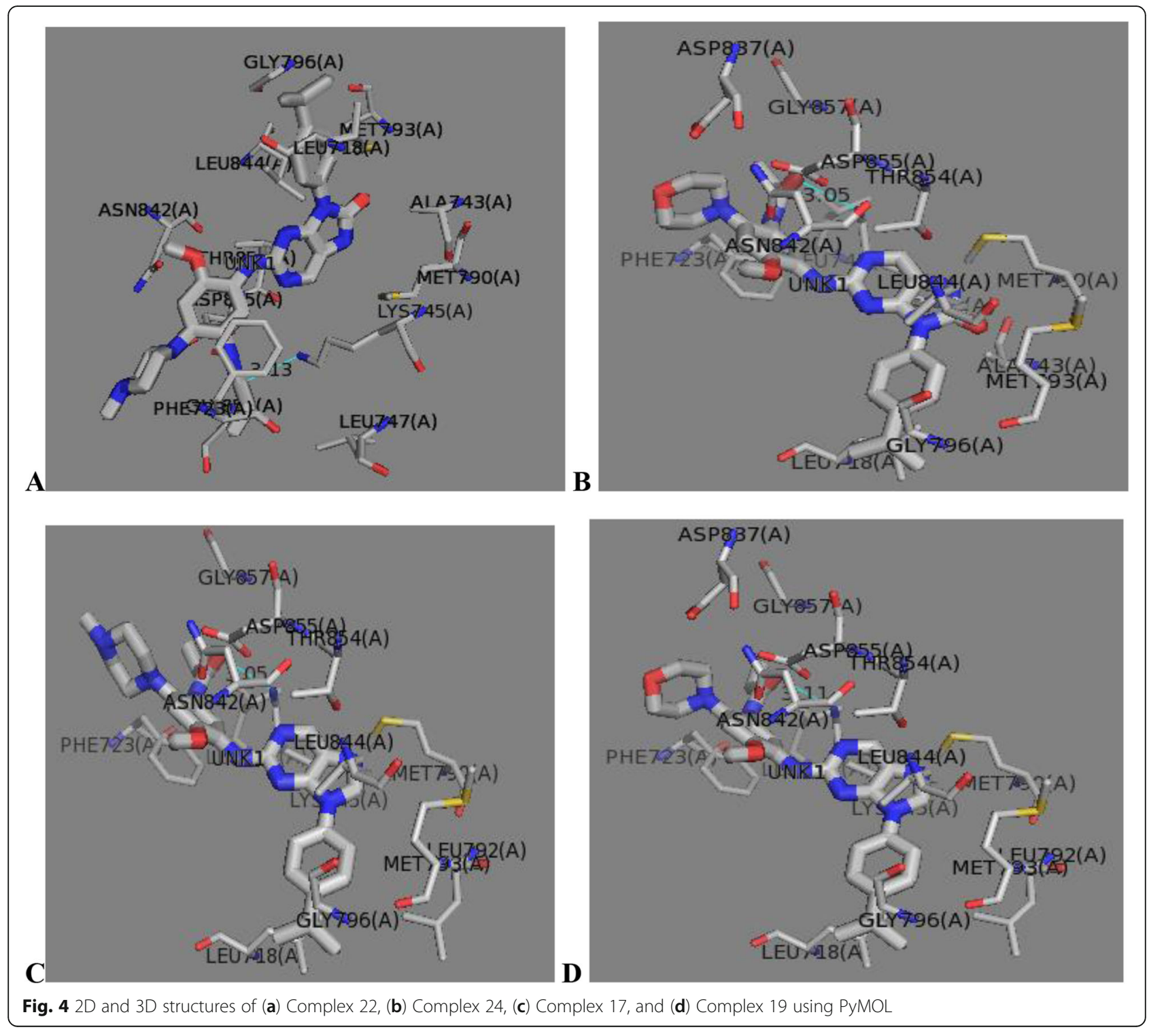


The EGFR enzyme with protein data bank code: 3IKA was retrieved from the RCSB protein data bank database. After successful retrieval of the enzyme, the preparation of the EGFR enzyme for the molecular docking simulation was done using discovery studio visualizer, in the process of the preparation of the enzyme, the cocrystalline ligand and molecule of water present on the structure were deleted. Before that, polar hydrogen was added. Figure 2 shows the 3D structure of the prepared EGFR enzyme.

The docking of the ligands to the binding pose of the EGFR enzyme was achieved with the help of Autodock vina of Pyrex virtual screening software [19]. After a successful docking procedure, since Pyrex was used there is a need to re-couple the docked ligand and the receptor for further investigation. UCSF Chimera software was used for the re-coupling of the docked ligand and the receptor. PyMOL and Discovery studio were used to achieve the visualization of recoupled complexes in order to view the nature of the interaction between the ligand and the receptor.

\section{Drug-likeness and ADME properties prediction}

Pharmacokinetics and drug-likeness of the EGFR ${ }^{\mathrm{L} 858 \mathrm{R} / \mathrm{T} 790 \mathrm{M}}$ inhibitors under investigation were determined using SwissADME, a free online web tool [20]. Lipinski's rule of five was the criteria used in the determination of the druglikeness of the molecules under investigation which states that if any small molecule violates more than 2 of these criteria, the molecules might not be orally bioavailable [21].

\section{Design}

Structure-based drug design is a very robust and useful technique. Structure-based drug design is also called direct design which involves the acquisition of the information regarding the three-dimensional structure of the

Table 3 Pharmacokinetics properties

\begin{tabular}{|c|c|c|c|c|c|c|}
\hline Molecule & MW & No. of H-bond acceptors & No. of H-bond donors & TPSA & WLOGP & No. of Lipinski's rule violations \\
\hline Molecule 1 & 486.57 & 6 & 2 & 100.44 & 3.5 & 0 \\
\hline Molecule 2 & 516.59 & 7 & 2 & 109.67 & 3.51 & 1 \\
\hline Molecule 3 & 500.6 & 6 & 2 & 100.44 & 3.81 & 0 \\
\hline Molecule 4 & 528.65 & 6 & 2 & 100.44 & 4.62 & 1 \\
\hline Molecule 5 & 514.62 & 6 & 2 & 100.44 & 4.06 & 1 \\
\hline Molecule 6 & 504.56 & 7 & 2 & 100.44 & 4.06 & 1 \\
\hline Molecule 7 & 521.01 & 6 & 2 & 100.44 & 4.15 & 1 \\
\hline Molecule 8 & 565.46 & 6 & 2 & 100.44 & 4.26 & 1 \\
\hline Molecule 9 & 612.47 & 6 & 2 & 100.44 & 4.1 & 1 \\
\hline Molecule 10 & 504.56 & 7 & 2 & 100.44 & 4.06 & 1 \\
\hline Molecule 11 & 521.01 & 6 & 2 & 100.44 & 4.15 & 1 \\
\hline Molecule 12 & 565.46 & 6 & 2 & 100.44 & 4.26 & 1 \\
\hline Molecule 13 & 555.46 & 6 & 2 & 100.44 & 4.81 & 1 \\
\hline Molecule 14 & 583.46 & 7 & 2 & 100.44 & 4.82 & 1 \\
\hline Molecule 15 & 539 & 7 & 2 & 100.44 & 4.71 & 1 \\
\hline Molecule 16 & 480.61 & 6 & 2 & 100.44 & 3.7 & 0 \\
\hline Molecule 17 & 526.63 & 6 & 2 & 100.44 & 3.62 & 1 \\
\hline Molecule 18 & 610.45 & 6 & 2 & 100.44 & 3.1 & 1 \\
\hline Molecule 19 & 513.59 & 6 & 2 & 106.43 & 4.08 & 1 \\
\hline Molecule 20 & 597.41 & 6 & 2 & 106.43 & 3.56 & 1 \\
\hline Molecule 21 & 628.46 & 6 & 3 & 120.41 & 3.4 & 1 \\
\hline Molecule 22 & 542.63 & 6 & 3 & 120.41 & 2.91 & 1 \\
\hline Molecule 23 & 626.45 & 6 & 3 & 120.41 & 2.39 & 1 \\
\hline Molecule 24 & 529.59 & 6 & 3 & 126.4 & 3.37 & 1 \\
\hline Molecule 25 & 613.41 & 6 & 3 & 126.4 & 2.86 & 1 \\
\hline Molecule 26 & 515.61 & 6 & 3 & 112.47 & 3.79 & 1 \\
\hline Molecule 27 & 543.66 & 6 & 3 & 112.47 & 4.83 & 1 \\
\hline Molecule 28 & 569.7 & 6 & 3 & 112.47 & 5.37 & 1 \\
\hline
\end{tabular}


molecular target (protein) through methods such as $\mathrm{x}$ ray crystallography, NMR spectroscopy, or homology modeling, followed by the design of suitable drug candidates based on the binding affinity and selectivity for their target molecules. Structure-based drug design comprises several steps such as protein structure retrieval and preparation, ligand library preparation, docking and manual design of new compounds [22].

\section{Results}

\section{Molecular docking simulation}

The results of the molecular docking simulation are presented in Table 2 and Figs. 3 and 4 respectively.

\section{Drug-likeness and ADME properties prediction}

The results of the drug-likeness and ADME properties prediction are presented in Tables 3 and 4, Figs. 5 and 6 respectively.

\section{Molecular docking of designed compounds}

The results of the molecular docking of designed compounds are presented in Tables 5 and 6 and Fig. 7 respectively.

\section{Drug-likeness and ADME properties prediction}

The result of the drug-likeness and ADME properties prediction is presented in Tables 7 and 8 , respectively.

\section{Discussion}

Molecular docking simulation

Molecular docking simulation was used to screen twenty-eight (28) sets of EGFR ${ }^{\mathrm{L} 858 \mathrm{R} / \mathrm{T} 790 \mathrm{M}}$ inhibitors in order to identify hit compounds that could be used to design new EGFR ${ }^{\mathrm{L} 858 \mathrm{R} / \mathrm{T} 790 \mathrm{M}}$ inhibitors by investigating their binding interactions in the binding pose of EGFR receptor (3IKA) (Table 2). The result of the four best hit

Table 4 Boiled-egg and CYP isoforms inhibition

\begin{tabular}{|c|c|c|c|c|c|c|c|c|}
\hline Molecule & Gl absorption & BBB permeant & Pgp substrate & CYP1A2 inhibitor & CYP2C19 inhibitor & CYP2C9 inhibitor & CYP2D6 inhibitor & $\begin{array}{l}\text { CYP3A4 } \\
\text { inhibitor }\end{array}$ \\
\hline Molecule 1 & High & No & Yes & No & Yes & Yes & Yes & Yes \\
\hline Molecule 2 & High & No & Yes & No & Yes & Yes & Yes & Yes \\
\hline Molecule 3 & High & No & No & No & Yes & Yes & Yes & Yes \\
\hline Molecule 4 & High & No & No & No & Yes & Yes & Yes & Yes \\
\hline Molecule 5 & High & No & No & No & Yes & Yes & Yes & Yes \\
\hline Molecule 6 & High & No & Yes & No & Yes & Yes & Yes & Yes \\
\hline Molecule 7 & High & No & No & No & Yes & Yes & Yes & Yes \\
\hline Molecule 8 & High & No & No & No & Yes & Yes & Yes & Yes \\
\hline Molecule 9 & High & No & No & No & Yes & Yes & Yes & Yes \\
\hline Molecule 10 & High & No & Yes & No & Yes & Yes & Yes & Yes \\
\hline Molecule 11 & High & No & No & No & Yes & Yes & Yes & Yes \\
\hline Molecule 12 & High & No & No & No & Yes & Yes & Yes & Yes \\
\hline Molecule 13 & High & No & No & No & Yes & Yes & Yes & Yes \\
\hline Molecule 14 & High & No & No & No & Yes & Yes & Yes & Yes \\
\hline Molecule 15 & High & No & No & No & Yes & Yes & Yes & Yes \\
\hline Molecule 16 & High & No & No & No & Yes & Yes & Yes & Yes \\
\hline Molecule 17 & High & No & Yes & No & Yes & Yes & Yes & Yes \\
\hline Molecule 18 & High & No & Yes & No & Yes & Yes & Yes & Yes \\
\hline Molecule 19 & High & No & Yes & No & Yes & Yes & Yes & Yes \\
\hline Molecule 20 & High & No & Yes & No & Yes & Yes & Yes & Yes \\
\hline Molecule 21 & High & No & Yes & No & Yes & Yes & Yes & Yes \\
\hline Molecule 22 & High & No & Yes & No & Yes & Yes & Yes & Yes \\
\hline Molecule 23 & High & No & Yes & No & Yes & Yes & Yes & Yes \\
\hline Molecule 24 & High & No & Yes & No & Yes & Yes & Yes & Yes \\
\hline Molecule 25 & High & No & Yes & No & Yes & Yes & Yes & Yes \\
\hline Molecule 26 & High & No & Yes & No & Yes & Yes & Yes & Yes \\
\hline Molecule 27 & High & No & No & No & Yes & Yes & Yes & Yes \\
\hline Molecule 28 & Low & No & Yes & No & Yes & Yes & Yes & Yes \\
\hline
\end{tabular}




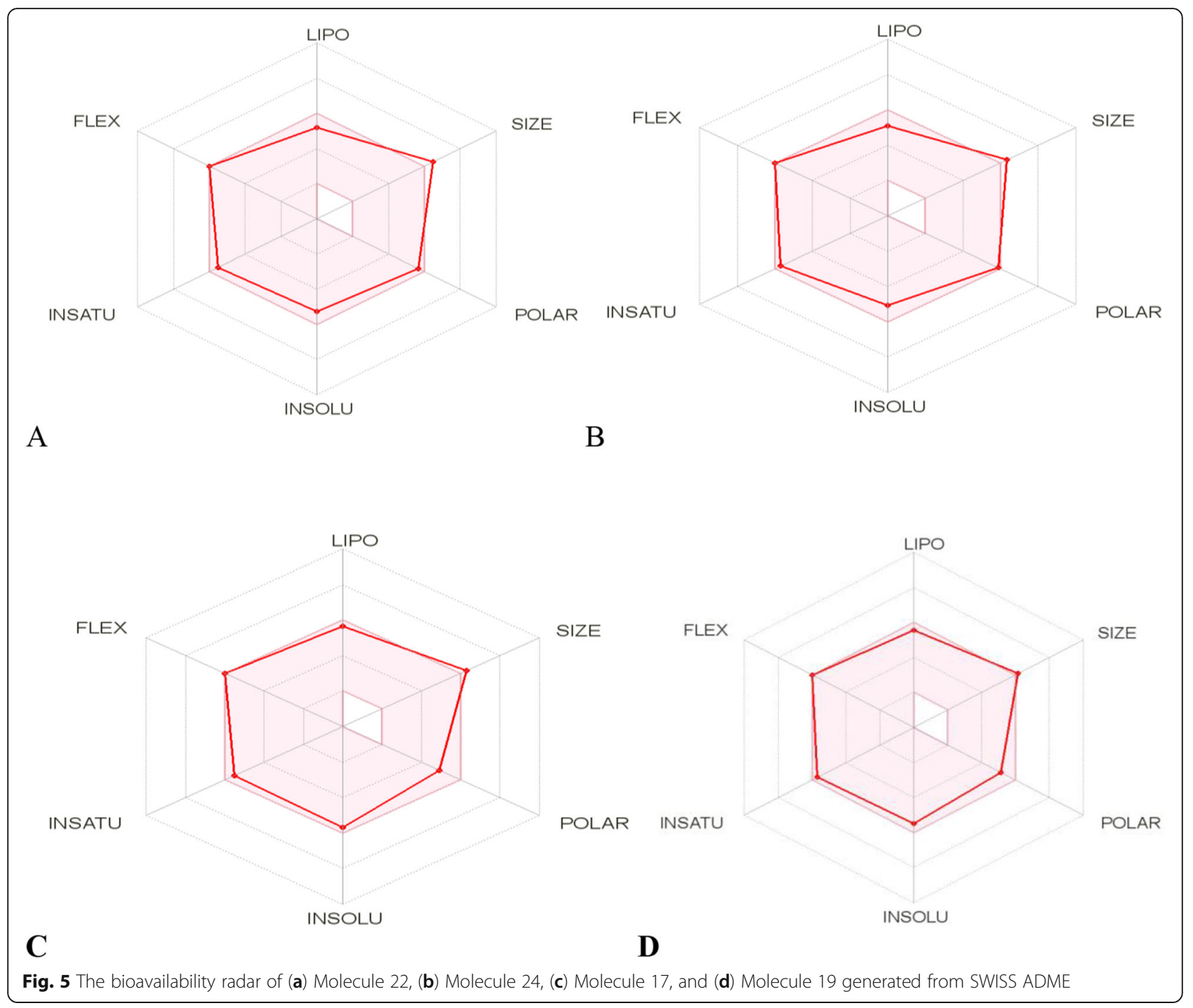

compounds with the lowest docking scores/highest binding affinity will be discussed.

Compound 22 was the best among the four selected compounds that have the lowest docking score of -9.8 $\mathrm{kcal} / \mathrm{mol}$ due to the major number of interactions in the binding pocket of the enzyme. Discovery studio visualizer was used to investigate its interaction in the binding pose of the enzyme, it was seen to interact with MET790 (2.65 $), \operatorname{LYS745~(2.67~\AA ⿱),~ASP855~(3.21~\AA ̊),~}$ GLY857 (3.69 $\AA$ ) and PHE723 (2.63 $\AA$ ) amino acid residues in the active site of EGFR receptor via both conventional and carbon-hydrogen bond interactions. Beside conventional and carbon-hydrogen bond interactions, it also bound to LEU844, PHE723, LEU718 (3), ALA743, and LEU844 residues via Pi-Sigma, Pi-Sulfur, Pi-Pi Stacked, Alkyl, and Pi-Alkyl hydrophobic interactions. Pi-Anion electrostatic interaction with ASP855 and Pi-Sulfur interaction with MET790 were also observed.
The second best with a binding affinity of $-9.7 \mathrm{kcal} /$ mol was compound 24 . It bound with LYS745 (2.58 $)$, ASN842 (3.47 ̊), GLY857 (3.72 ̊), and PHE723 (2.54 $\AA$ ) residues in the binding pose of the receptor through conventional and carbon-hydrogen bond interactions. Pi-Sigma, Pi-Pi Stacked, Alkyl, and Pi-Alkyl hydrophobic interactions were also observed with ASP855, LEU844 (2), PHE723, LEU718 (3), VAL726, and ALA743 residues. Apart from the interaction mentioned, Pi-Anion electrostatic interaction with ASP855 and Pi-Sulfur interaction with MET790 amino acid residues respectively were also seen.

The third best in the trend is compound 17 which also found to bound via conventional and carbonhydrogen bond interactions with MET790 (2.57 $\AA$ ),

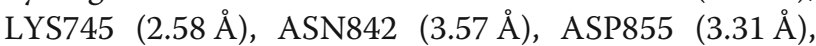
GLY857 (3.71 $\AA$ ), and PHE723 (2.69 $)$ amino acid residues respectively. Apart from conventional and carbon-hydrogen bond interactions, it interacted via 

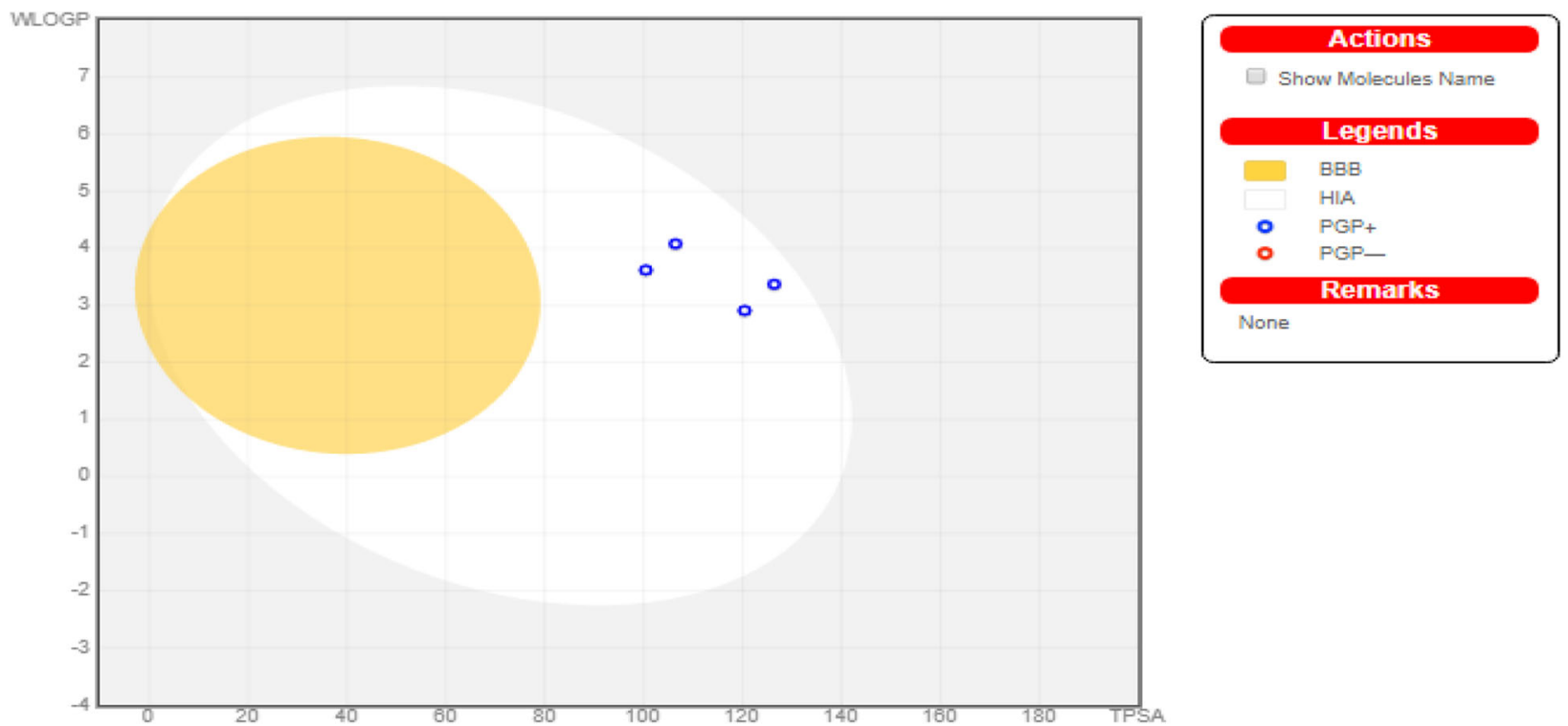

Fig. 6 Boiled-egg Plot of the lead compounds generated from SWISS ADME

Pi-Sigma, Pi-Pi Stacked, Alkyl, and Pi-Alkyl hydrophobic interactions with PHE723, LEU718 (3), LEU792, and LEU844 amino acid residues and also via Pi-Sulfur with MET790 amino acid residue in the binding pose of the receptor. The last one in the trend is compound 19 which also bound with the active site of the receptor via conventional and carbon-hydrogen bond interactions, PiSigma, Pi-Pi Stacked, Alkyl, Pi-Alkyl hydrophobic interactions, and Pi-Anion electrostatic interactions as shown in Table 2. Figures 3 and 4 showed the $2 \mathrm{D}$ and $3 \mathrm{D}$ structures of the four lead compounds investigated using discovery studio visualizer and Pymol.

\section{Drug-likeness and ADME properties prediction of the studied compounds}

Table 3 presents the computed drug-likeness of the compounds under investigation. It was observed in the table that none of the molecules under investigation violated more than the maximum permissible limit of the criteria stated by Lipinski's filters, it therefore means that there is a high tendency that all of these molecules might be pharmacologically very active. In fact, all these molecules under investigation are said to have good absorption, low toxicity level, orally bioavailable, and permeable properties except molecule 28 which has WlogP value (it predicts whether a molecule has low toxicity level or not) greater than 5. The Bioavailability Radar of the four selected molecules under investigation was shown to further confirm their drug-likeness properties (Fig. 5). The compounds under investigation could be said to be orally bioavailable.
Table 4 presents the gastrointestinal (GI) absorption, blood-brain barrier (BBB) permeant, Pgp substrate, and CYP isoforms inhibition properties of all the molecules under investigation. From the table, all the molecules under investigation have high GI absorption, none has $\mathrm{BBB}$ permeant, some were found to be able to permeate through the skin and some cannot, also all were observed to inhibit the CYP isoforms except CYP1A2. The boiled-egg plot was performed to further confirm the GI absorption and BBB permeant properties of the four hit compounds (Fig. 6). It is further confirmed from the plot that none of them passed through the BBB but they were within the GI absorption region.

\section{Molecular docking of designed compounds}

Six new EGFR ${ }^{\mathrm{L} 858 \mathrm{R} / \mathrm{T} 790 \mathrm{M}}$ inhibitors were designed using compound 22 with the highest binding affinity of -9.8 $\mathrm{kcal} / \mathrm{mol}$ as the template (Table 5). Based on the interaction of compound 22 with the EGFR receptor, structural modifications were carried out on the template by the addition of substituents on the piperazin-1-yl moiety and isopropyl phenyl ring of the template.

The addition of acetyl group on the piperazin-1-yl moiety and 2 chlorine molecules at the meta position of the isopropyl phenyl ring of the template showed a significant increase in the interaction of the designed compound (D3) with the EGFR receptor with $-10.2 \mathrm{kcal} / \mathrm{mol}$ binding energy. It was found to bind with the EGFR receptor through conventional and carbon-hydrogen bonds, hydrophobic, electrostatic, and other interactions (Table 6). Four amino acid residues (ASP855, MET790, LYS745, and LYS745) of the enzyme with bond distance $2.9622 \AA, 2.49526 \AA, 2.61911 \AA$, and $2.38759 \AA$ were 
Ibrahim et al. Future Journal of Pharmaceutical Sciences

(2020) 6:55

Page 12 of 16

Table 5 The designed compounds with their binding affinities

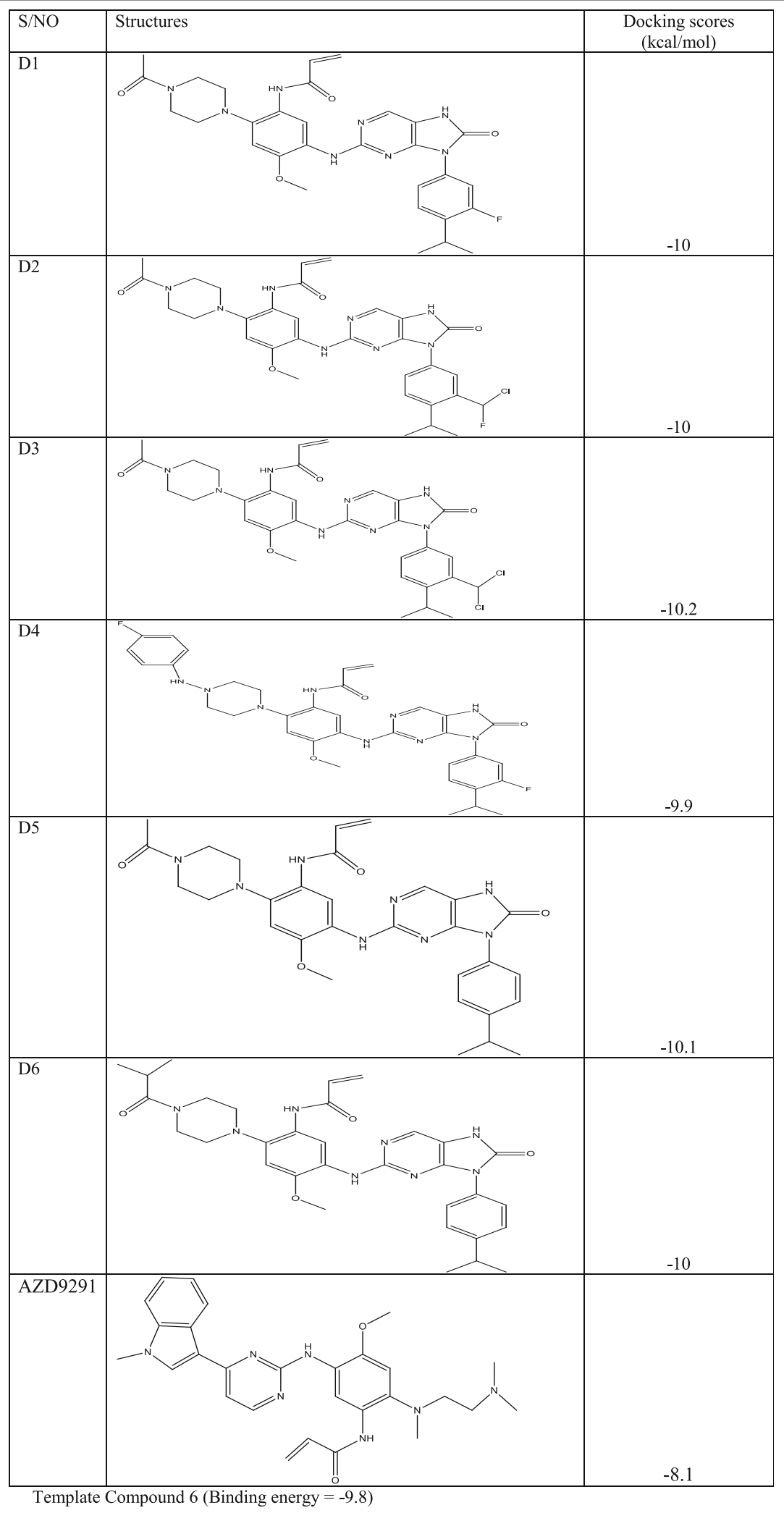

Template Compound 6 (binding energy $=-9.8$ ) 
Table 6 The interactions of the designed compounds in the active site of the EGFR receptor

\begin{tabular}{|c|c|c|c|c|}
\hline $\begin{array}{l}\text { Ligand receptor } \\
\text { (3IKA) }\end{array}$ & $\begin{array}{l}\text { Binding energy } \\
(\mathrm{kcal} / \mathrm{mol})\end{array}$ & Hydrogen bond & $\begin{array}{l}\text { Bond } \\
\text { distance }(\AA)\end{array}$ & Hydrophobic and other interactions \\
\hline 1 & -10 & $\begin{array}{l}\text { ASP855, MET790, } \\
\text { LYS745, LYS745, } \\
\text { ASP855 \& PHE723 }\end{array}$ & $\begin{array}{l}2.91264, \\
2.46131 \\
2.6733 \\
2.46143 \\
3.29523 \& \\
2.58927\end{array}$ & $\begin{array}{l}\text { ASP855, LEU718 (3), MET790, PHE723, LEU792, ALA743 } \\
\text { \& LEU844 (2) }\end{array}$ \\
\hline 2 & -10 & $\begin{array}{l}\text { ASP855, MET790, } \\
\text { LYS745, ASP855 \& PHE723 }\end{array}$ & $\begin{array}{l}2.81294 \\
2.45287 \\
2.74079 \\
3.36729 \& \\
2.75797\end{array}$ & $\begin{array}{l}\text { ASP855, LEU844 (3), MET790, } \\
\text { PHE723, LEU718 (4), LEU792, CYS797 \& ALA743 (2) }\end{array}$ \\
\hline 3 & -10.2 & $\begin{array}{l}\text { ASP855, MET790, } \\
\text { LYS745, LYS745, } \\
\text { ASP855 \& PHE723 }\end{array}$ & $\begin{array}{l}2.9622, \\
2.49526 \\
2.61911 \\
2.38759 \\
3.24379 \& \\
2.57647\end{array}$ & $\begin{array}{l}\text { ASP855, LEU844 (2), MET790, PHE723, LEU718 (3), LEU792, } \\
\text { CYS797 \& ALA743 (2) }\end{array}$ \\
\hline 4 & -9.9 & $\begin{array}{l}\text { ASP855, THR854 \& } \\
\text { PHE723 }\end{array}$ & $\begin{array}{l}2.6829 \\
2.50494 \& \\
3.54003\end{array}$ & $\begin{array}{l}\text { ASP855, LEU718, GLY796, PHE723, GLY857, ALA755, LEU747, } \\
\text { ILE759, VAL726 \& LEU858 (2) }\end{array}$ \\
\hline 5 & -10.1 & $\begin{array}{l}\text { ASP855, MET790, } \\
\text { LYS745, LYS745, } \\
\text { ASP855 \& PHE723 }\end{array}$ & $\begin{array}{l}2.83123 \\
2.35804 \\
2.58025 \\
2.43397 \\
3.31176 \& \\
2.70789\end{array}$ & $\begin{array}{l}\text { ASP855, LEU718 (3), MET790, PHE723, LEU792, ALA743 } \\
\text { \& LEU844 (2) }\end{array}$ \\
\hline 6 & -10 & $\begin{array}{l}\text { MET790, LYS745, ASP855 } \\
\& \text { PHE723 }\end{array}$ & $\begin{array}{l}2.45034 \\
2.68227 \\
3.3187 \& \\
2.46677\end{array}$ & $\begin{array}{l}\text { ASP855, LEU718 (3), MET790, PHE723, LEU792, LEU858 } \\
\text { (2), LYS875 (2), ALA743 \& LEU844 }\end{array}$ \\
\hline AZD9291 & -8.1 & $\begin{array}{l}\text { ASP855, ASP837 \& } \\
\text { GLY857 }\end{array}$ & $\begin{array}{l}2.39196 \\
3.61636 \& \\
3.55164\end{array}$ & MET790, LEU718, VAL726 LEU844 (2) \& ALA743 (2) \\
\hline
\end{tabular}

Template: Compound 22 (binding energy $=-9.8$ )

observed to form a conventional hydrogen bond with a different part of the ligand as depicted in Fig. 7a. Carbon-hydrogen bond was also observed in the binding pocket of the enzyme between these two amino acid residues ASP855 (3.24379 $\AA$ ) and PHE723 (2.57647 $\AA$ ) and the ligand. The ten (10) amino acid residues in the binding pocket of the enzyme who interacted with the ligands via hydrophobic interaction were LEU844 (2), MET790, PHE723, LEU718 (3), LEU792, CYS797, and ALA743 (2) respectively. Besides the mentioned interactions, electrostatic interaction was also observed between the ligand (D3) and ASP855 residue in the binding pocket of the receptor. The only amino acid who interacted via Pi-Sulfur interaction (other) was MET790.

The addition of only the acetyl group on the piperazin-1-yl moiety of the template yielded significant change also in the interaction of the designed compound (D5) with the EGFR receptor with a very good binding affinity of $-10.1 \mathrm{kcal} / \mathrm{mol}$ (Table 5). Designed compound D5 bounded to EGFR receptor via a hydrogen bond, hydrophobic interactions, and other interaction as shown in Table 6. The same number of the conventional

Table 7 Drug-likeness properties of the designed compounds

\begin{tabular}{|c|c|c|c|c|c|c|}
\hline Molecule & MW & TPSA & WLOGP & No. of H-bond donors & No. of $\mathrm{H}$-bond acceptors & RO5 violations \\
\hline Molecule 1 & 588.63 & 137.48 & 3.38 & 3 & 10 & 2 \\
\hline Molecule 2 & 637.1 & 137.48 & 4.13 & 3 & 11 & 2 \\
\hline Molecule 3 & 653.56 & 137.48 & 3.98 & 3 & 11 & 2 \\
\hline Molecule 4 & 655.7 & 132.44 & 4.23 & 4 & 11 & 2 \\
\hline Molecule 5 & 570.64 & 137.48 & 2.83 & 3 & 6 & 1 \\
\hline Molecule 6 & 598.7 & 137.48 & 3.46 & 3 & 6 & 1 \\
\hline
\end{tabular}




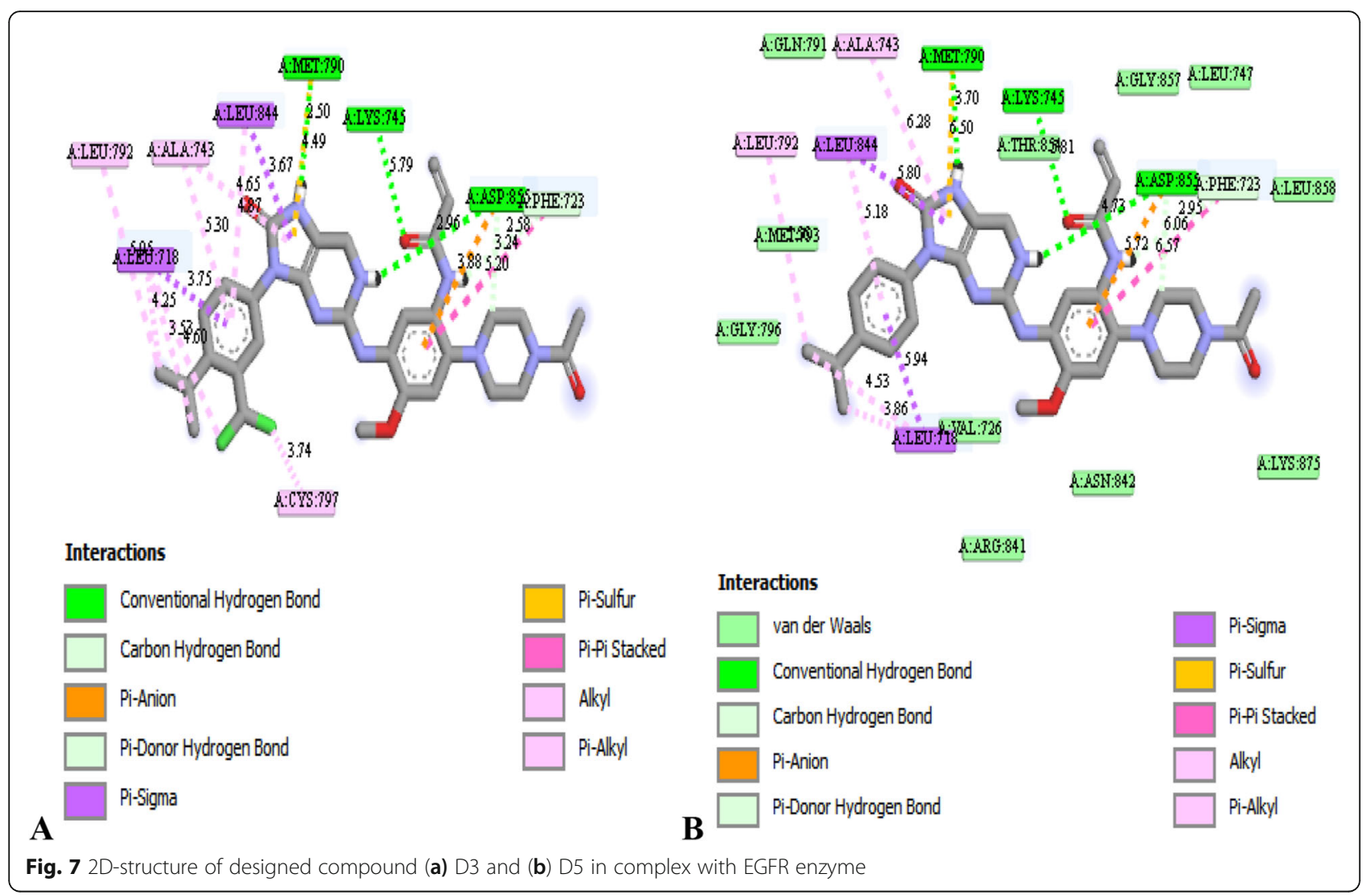

hydrogen bond, carbon-hydrogen bond, electrostatic, and Pi-Sulfur (other) interactions were observed between D5 and the receptor except in the hydrophobic interaction where there were eight amino acids which interacted with the ligand. The four amino acid residues with the bond distance that interacted via conventional hydrogen bond with a different part of the ligand as shown in Fig. 7b were ASP855 (2.83123 $\AA$ ), MET790

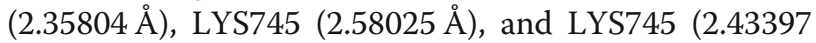
$\AA$ ) respectively. The two amino acids that were observed to the carbon-hydrogen bond in the binding pocket of the enzyme and the ligand were ASP855 (3.31176 $)$ and PHE723 (2.70789 $\AA$ ). The eight (8) amino acid residues in the binding pocket of the enzyme which interacted with the ligands via hydrophobic interaction were LEU718 (3), PHE723, LEU792, ALA743, and LEU844 (2) respectively. Besides the mentioned interactions, ASP855 residue was the only that form electrostatic interaction between the ligand and in the binding pocket of the receptor and MET790 was the only residue who interacted via Pi-Sulfur (other) interaction. This might be possible as the result of not having halogens in the designed compound 5 (D5) which is why the number of hydrophobic interactions were less than that of D3.

The other designed compounds (D1, D2, D4, and D6) showed good interactions with higher binding affinity in the binding pocket of the EGFR tyrosine kinase receptor (Table 6). They were observed to have interacted with the binding pocket of the enzyme via the same conventional hydrogen, carbon-hydrogen bond, hydrophobic, electrostatic, and Pi-Sulfur (other) interactions except D4 which has not interacted via

Table 8 ADME Properties of the designed compounds

\begin{tabular}{llllll}
\hline Molecule & Gl absorption & BBB permeant & Pgp substrate & Bioavailability Score & Synthetic Accessibility \\
\hline Molecule 1 & Low & No & Yes & 0.17 & 4.22 \\
Molecule 2 & Low & No & Yes & 0.17 & 4.88 \\
Molecule 3 & Low & No & No & 0.17 & 4.37 \\
Molecule 4 & Low & No & No & 0.17 & 4.68 \\
Molecule 5 & Low & No & Yes & 0.17 & 4.17 \\
Molecule 6 & Low & No & Yes & 0.17 & 4.4 \\
\hline
\end{tabular}


Pi-Sulfur (other) interaction. Furthermore, AZD9291 was used as a positive control and used to validate the docking process than compared with the designed compounds. The designed compounds were found to be better than AZD9291 which has the binding affinity of $-8.1 \mathrm{kcal} / \mathrm{mol}$ which is as a result of less number of interactions as compared with the designed compounds. The 2D structures of designed compound D3 and D5 are presented in Fig. 7a and b.

\section{Drug-likeness and ADME prediction of designed compounds}

Using the Lipinski's rule of five as a standard filter for small molecule, the drug-likeness of the designed compounds were also predicted as presented in Table 7. From the table, no any designed compound was found to violate more than the permissible limit set by Lipinski's rule of five filters and therefore predicting their easy transportation, absorption, and diffusion [23, 24].

ADME properties of these designed compounds were also predicted and presented in Table 8 . All were observed to have low gastrointestinal absorption. But none was observed to permeant through the brain. All designed compounds have a lower bioavailability score of 0.17 . Based on the synthetic accessibility score (Table 8), they can all be synthesized in the laboratory $[25,26]$.

\section{Conclusion}

In conclusion, molecular docking simulation carried out on the twenty-eight (28) EGFR ${ }^{\mathrm{L} 858 \mathrm{R} / \mathrm{T} 790 \mathrm{M}}$ inhibitors has identified four hit compounds with a higher binding affinity toward their target. The hit compounds discovered were compound 22 with $-9.8 \mathrm{kcal} /$ $\mathrm{mol}, 24$ with $-9.7 \mathrm{kcal} / \mathrm{mol}, 17$ with $-9.7 \mathrm{kcal} / \mathrm{mol}$, and 19 with $-9.5 \mathrm{kcal} / \mathrm{mol}$ respectively. These lead compounds were further subjected to drug-likeness and ADME prediction and found to be orally bioavailable with good absorption, low toxicity level, and permeable properties. The best among the hit compounds was retained as a template and used to design six new EGFR ${ }^{\mathrm{L} 858 \mathrm{R} / \mathrm{T} 790 \mathrm{M}}$ inhibitors with better binding affinity than the template and AZD9291 (the positive control). None of the designed compounds was found to violate more than the permissible limit set by RO5 thereby predicting their easy transportation, absorption, and diffusion. More so, the designed compounds were found to have good synthetic accessibility which indicates that these designed compounds can be synthesized in the laboratory.

\section{Abbreviations}

DFT: Density function theory; B3LYP: Becke's three-parameter read-Yang-Parr hybrid; PDB: Protein data bank; NSCLC: Non-small cell lung cancer agents; EGFR: Epidermal growth factor receptor

\section{Acknowledgements}

The authors acknowledge the technical effort of Ahmadu Bello University, Zaria - Nigeria

\section{Authors' contributions}

MTI contributed throughout the research work. AU gives directives and technical advice. GAS partake in technical activities. SU also partake in technical activities. All authors have read and approved the manuscript.

Funding

This research did not receive any funding from anybody.

Availability of data and materials

All data and materials are available upon request.

Ethics approval and consent to participate

Not applicable.

Consent for publication

Not applicable.

Competing interests

All authors have declared that there is no conflict of interest regarding this submission.

Received: 5 June 2020 Accepted: 6 August 2020

Published online: 18 August 2020

\section{References}

1. Kong L-L, Ma R, Yao M-Y, Yan X-E, Zhu S-J, Zhao P, Yun C-H (2017) Structural pharmacological studies on EGFR T790M/C797S. Biochem Biophys Res Commun 488(2):266-272

2. Song J, Jang S, Lee JW, Jung D, Lee S, Min KH (2019) Click chemistry for improvement in selectivity of quinazoline-based kinase inhibitors for mutant epidermal growth factor receptors. Bioorg Med Chem Lett 29(3):477-480

3. Hanan EJ, Baumgardner M, Bryan MC, Chen Y, Eigenbrot C, Fan P, Gu X-H, La H, Malek S, Purkey HE (2016) 4-Aminoindazolyl-dihydrofuro [3, 4-d] pyrimidines as non-covalent inhibitors of mutant epidermal growth factor receptor tyrosine kinase. Bioorg Med Chem Lett 26(2):534-539

4. Balak MN, Gong Y, Riely GJ, Somwar R, Li AR, Zakowski MF, Chiang A, Yang G, Ouerfelli O, Kris MG (2006) Novel D761Y and common secondary T790M mutations in epidermal growth factor receptor-mutant lung adenocarcinomas with acquired resistance to kinase inhibitors. Clin Cancer Res 12(21):6494-6501

5. Dungo RT, Keating GM (2013) Afatinib: first global approval. Drugs 73(13): 1503-1515

6. Solca F, Dahl G, Zoephel A, Bader G, Sanderson M, Klein C, Kraemer O, Himmelsbach F, Haaksma E, Adolf GR (2012) Target binding properties and cellular activity of afatinib (BIBW 2992), an irreversible ErbB family blocker. J Pharmacol Exp Ther 343(2):342-350

7. Tsao M-S, Sakurada A, Cutz J-C, Zhu C-Q, Kamel-Reid S, Squire J, Lorimer I, Zhang T, Liu N, Daneshmand M (2005) Erlotinib in lung cancer-molecular and clinical predictors of outcome. N Engl J Med 353(2):133-144

8. Cross DA, Ashton SE, Ghiorghiu S, Eberlein C, Nebhan CA, Spitzler PJ, Orme JP, Finlay MRV, Ward RA, Mellor MJ (2014) AZD9291, an irreversible EGFR TKI, overcomes T790M-mediated resistance to EGFR inhibitors in lung cancer. Cancer discovery 4(9):1046-1061

9. Walter AO, Sjin RTT, Haringsma HJ, Ohashi K, Sun J, Lee K, Dubrovskiy A, Labenski M, Zhu Z, Wang Z (2013) Discovery of a mutant-selective covalent inhibitor of EGFR that overcomes T790M-mediated resistance in NSCLC. Cancer discovery 3(12):1404-1415

10. Park, K., J.-S. Lee, K.H. Lee, J.-H. Kim, B.C. Cho, Y.J. Min, J.Y. Cho, J.-Y. Han, B.-S. Kim, and J.S. Kim, (2016), Olmutinib (BI 1482694; HM61713), an EGFR mutant-specific inhibitor, in T790M+ NSCLC: efficacy and safety at the RP2D, J Clin Oncol, 34 (suppl), abstr 9055.

11. Paz-Ares L, Tan E-H, O'byrne K, Zhang L, Hirsh V, Boyer M, Yang J-H, Mok T, Lee K, Lu S (2017) Afatinib versus gefitinib in patients with EGFR mutationpositive advanced non-small-cell lung cancer: overall survival data from the phase IIb LUX-Lung 7 trial. Ann Oncol 28(2):270-277

12. Song Z, Ge Y, Wang C, Huang S, Shu X, Liu K, Zhou Y, Ma X (2016) Challenges and perspectives on the development of small-molecule EGFR 
inhibitors against T790M-mediated resistance in non-small-cell lung cancer: miniperspective. J Med Chem 59(14):6580-6594

13. Beheshti A, Pourbasheer E, Nekoei M, Vahdani S (2016) QSAR modeling of antimalarial activity of urea derivatives using genetic algorithm-multiple linear regressions. Journal of Saudi Chemical Society 20(3):282-290

14. Khan, M.F., G. Verma, W. Akhtar, M. Shaquiquzzaman, M. Akhter, M.A. Rizvi, and M.M. Alam, (2016), Pharmacophore modeling, 3D-QSAR, docking study and ADME prediction of acyl 1, 3, 4-thiadiazole amides and sulfonamides as antitubulin agents, Arabian Journal of Chemistry,

15. Hu J, Han Y, Wang J, Liu Y, Zhao Y, Liu Y, Gong P (2018) Discovery of selective EGFR modulator to inhibit L858R/T790M double mutants bearing a N-9-Diphenyl-9H-purin-2-amine scaffold. Bioorg Med Chem 26(8):1810-1822

16. Ibrahim MT, Uzairu A, Shallangwa GA, Ibrahim A (2018) Computational studies of some biscoumarin and biscoumarin thiourea derivatives ASaGLUCOSIDASE INHIBITORS. The Journal of Engineering and Exact Sciences 4(2):0276-0285

17. Kohn W, Becke AD, Parr RG (1996) Density functional theory of electronic structure. J Phys Chem 100(31):12974-12980

18. Adeniji, S.E., S. Uba, and A. Uzairu, (2018), Quantitative structure-activity relationship and molecular docking of 4-Alkoxy-Cinnamic analogues as antimycobacterium tuberculosis, Journal of King Saud University-Science,

19. Ibrahim, M.T., A. Uzairu, G.A. Shallangwa, and A. Ibrahim, (2018), In-silico studies of some oxadiazoles derivatives as anti-diabetic compounds, Journal of King Saud University-Science,

20. Daina A, Michielin O, Zoete V (2017) SwissADME: a free web tool to evaluate pharmacokinetics, drug-likeness and medicinal chemistry friendliness of small molecules. Sci Rep 7:42717

21. Ismail, S.Y., A. Uzairu, B. Sagagi, and M. Sabiu, (2018), In silico molecular docking and pharmacokinetic study of selected phytochemicals with estrogen and progesterone receptors as anticancer agent for breast cancer, 5 (3), 1337-1350

22. Batool M, Ahmad B, Choi S (2019) A structure-based drug discovery paradigm. Int J Mol Sci 20(11):2783

23. Ibrahim MT, Uzairu A, Shallangwa GA, Uba S (2020) Computer-aided molecular modeling studies of some 2, 3-dihydro-[1, 4] dioxino [2, 3-f] quinazoline derivatives as EGFR WT inhibitors. Beni-Suef University Journal of Basic and Applied Sciences 9:1-10

24. Khan I, Garikapati KR, Setti A, Shaik AB, Makani VKK, Shareef MA, Rajpurohit H, Vangara N, Pal-Bhadra M, Kamal A (2019) Design, synthesis, in silico pharmacokinetics prediction and biological evaluation of 1, 4dihydroindeno [1, 2-c] pyrazole chalcone as EGFR/Akt pathway inhibitors. Eur J Med Chem 163:636-648

25. Ibrahim MT, Uzairu A, Shallangwa GA, Uba S (2020) In-silico activity prediction and docking studies of some 2, 9-disubstituted 8-phenylthio/ phenylsulfinyl-9 h-purine derivatives as Anti-proliferative agents. Heliyon 6(1):e03158

26. Hosen S, Dash R, Khatun M, Akter R, Bhuiyan MHR, Rezaul M, Karim NJM, Ahamed F, Islam KS, Afrin S (2017) In silico ADME/T and 3D QSAR analysis of KDR inhibitors. Journal of Applied Pharmaceutical Science 7(01):120-128

\section{Publisher's Note}

Springer Nature remains neutral with regard to jurisdictional claims in published maps and institutional affiliations.

\section{Submit your manuscript to a SpringerOpen ${ }^{\circ}$ journal and benefit from:}

- Convenient online submission

- Rigorous peer review

- Open access: articles freely available online

- High visibility within the field

- Retaining the copyright to your article

Submit your next manuscript at $\boldsymbol{\nabla}$ springeropen.com 